\title{
Editorial Lies, gags and the future
}

T'S one thing for a president to lie about his sex life,' wryly observed Al Franken. 'It's another to lie about why we are sending our young men and women into battle.' This was a snippet in response to Robert Greenwald's controversial documentary Uncovered: The Whole Truth about the Iraq War (2003). Compelling footage of George W. Bush, Condoleeza Rice and Dick Cheney plus a damning dossier compiled by intelligence analysts, politicians and diplomats stripped away the fig leaf of deceit presented to Congress and the United Nations as part of the so-called 'war on terror'. Just as the American people were deceived over the Vietnam War about the 'Tonkin Gulf Incident' hoax in 1964, so they were lied to over Saddam Hussein's relationship with al-Qaeda and the so-called existence of weapons of mass destruction. And just as Greenwald's claims became well-known and supported by later official revelations, a US National Security Agency historian has chronicled the Tonkin Gulf cover-up and aftermath. As professor Ben Kiernan puts it:

A non-existent 'attack' then became a lie that took the United States into a new war against North Vietnam, at a cost of 58,000 American lives and over a million Vietnamese. It now seems clear that not one but both of the most disastrous conflicts in US history, those in Vietnam and Iraq, were sparked by US officials disseminating lies and convincing the American public to go to war. (Kiernan, 2005)

While Uncovered, and a companion film, Unconstitutional, exposing how the erosion of US civil liberties was impacting on ordinary law-abiding Americans, have a critical edge over more recent documentaries and feature films - such as United 93, the Paul Greengrass portrayal of the only plane not to reach its target on that tragic day, and Oliver Stone's World Trade Centreone mini-documentary stands out as a contender for the propaganda Oscar of the year. Described by critics as 'appalling', The Pathway to 9/11 was a 'fictional retelling' of both the 1993 bombing at the World Trade Centre basement in New York and the events leading up to the attacks on 11 September 
2001 (Cheng, 2006). But while the ABC's Pathway faced a barrage of protests in the US, which eventually led to several 11th hour changes (not in the version shown in New Zealand), the debate about the merits of this programme — stretched truth or propaganda? — was relatively muted here. Nevertheless, two Auckland University law lecturers, Kevin Heller and John Ip, filed a formal complaint with the Broadcasting Standards Authority (BSA). As columnist William E. Jackson observed in his Huffington Post blog:

\begin{abstract}
What was the ABC's answer to why? Key officials from [former] President Clinton on down through Madeleine Albright and Sandy Burger and George Tenet were either asleep at the switch prior to 2001, or impeachably negligent, or excessively timid in taking on the terrorists led by Osama bin Laden. In other words, this fiction-non-fiction tale was neatly tailored to fit the Bush/Cheney/Rumsfield/Rove mantra of the Democrats being soft on terrorism and not understanding the true nature of the enemy in the World War III battle with 21 st century fascism. Iraq is barely in the picture. (Jackson, 2006)
\end{abstract}

In the new age, there is clearly an expectation in some quarters that bureaucrats and policymakers should be set free to break or skirt the law. The implication is that the US government needs to be free to assassinate or torture suspects.

In this context, when the news media's contemporary role is closer to a lapdog than a watchdog, then the future seems rather disturbing. As Sri Lankanborn Australian media analyst and journalist Kalinga Seneviratne notes in a polemic in this edition of Pacific Journalism Review examining regional security following the 9/11 debacle, the US and its 'axis of freedom' allies have had second thoughts about human rights.

The US Patriot Act and British and Australian anti-terror laws passed in 2005 have been criticised by human rights groups within their own countries for curtailing basic freedoms... As journalists, we need to raise these points and ask the questions rather than cheerlead the government of Bush, Blair and Howard. (p. 40)

Seneviratne is particularly scathing about what he describes as 'parrot journalism'-absorbing Western 'prejudices and stereotypes' and reproducing these in media in the journalist's own language. Seneviratne is far from alone 
in his concerns about the role of Western media, as is indicated by Andrea King in a review of a sobering new book, Feet to the Fire, that investigates how journalists abdicated their watchdog role in the run-up to the invasion (p. 103). Mark Pearson and Naomi Busst's research article examines antiterror laws and their impact on the media in Australia, New Zealand and the Pacific: 'Sadly, the Australian approach seems to have eroded the democratic foundation stone of press freedom, which can be seen as serving the ultimate goals of the very terrorism they were meant to counter' (p. 24).

In 'From Fiji to Fallujah', Nic Maclellan exposes how the Iraq War has fuelled the privatisation of the Pacific security. Former Fiji soldiers are keen to make a living by being recruited for the mercenary forces of the Middle East (and the Pacific in a bizarre case in Bougainville). Maclellan notes that while the Iraq conflict has been a global tragedy, the 'ongoing chaos caused by the US occupation is spreading insecurity as far as the South Pacific'.

Som Prakash and Shailendra Singh examine the political arena in Fiji, Tonga and the Solomon Islands and how conflict has impacted on the media. Noting that while the media is often blamed for insecurity, such claims are 'mostly by leaders who fear change and the accompanying loss of privileges'. They pay a tribute to the role of the media in exposing government misdeeds and becoming a catalyst for positive change for accountability and better democracy in the region.

Patrick Matbob and Evangelia Papoutsaki explore the issue of Indonesian-ruled West Papua and the independence movement and how it is covered by the Papua New Guinean press. They conclude there has been a 'dramatic decline' in reportage in the past two decades. This is in spite of the conflict being unresolved and with growing awareness in other countries.

Photojournalist Ben Bohane bridges security issues and the environment with an evocative portfolio of photos on 'spirit and war' in Melanesia, published to mark his current new exhibition in Sydney. In fact, for many in the region, and also globally, security is not the crucial issue. Environmental issues are far more pressing. As British government chief scientific adviser Sir David King put it in Science (2004), 'Climate change is the most severe problem that we are facing today-more serious even than the threat of terrorism.' His article stirred controversy and there was an attempt to gag him. With many atoll nations in the Pacific, such as Kiribati and Tuvalu, acutely at risk from global warming, the environment should be a far greater priority with the region's media. But is it? 
According to environmental journalist and commentator Samir S. Patel, a Pulitzer travelling fellow in the region, far more needs to be done. Referring to what he calls 'islands of understanding', he says that 'unless steps are taken to make the environment a priority' the fate of the atolls are a warning about the fate of continents. Ian Spellerberg, Graeme Buchan and Nick Early are critical about the state of New Zealand television and environmental sustainability. They argue for an environmental code of standards. Chris Nash and Wendy Bacon opt for a wider canvas and examine six Englishlanguage newspapers in Southeast Asia, and also make a side comparison with a leading Australian newspaper. Their study examines the intricacies of complex patterns of private ownership and the engagement of both capitalist and communist governments in multi-dimensional relationships. At the same time, environmental journalism has become well-established across the Southeast Asian media.

Finally, in the Dialogue section, New Zealand journalist Alison McCulloch contributes the text of an insightful discussion with two New York Times journalists, Joseph Kahn and Jim Yardley, on the future of China. The journalists provide a fascinating glimpse into the environmental and industrial dilemmas challenging China's political system.

\section{Dr David Robie}

Associate Professor

School of Communication Studies

AUT University

\section{References}

Cheng, D. (2006, September 11). TVNZ faces formal complaint over controversial series. New Zealand Herald, p. A8.

Greenwald, R. (2003). Uncovered: The Whole Truth about the Iraq War. New York: MoveOn.org and the Center for American Progress.

Jackson, W. E. (2006, September 9). The hidden agenda of ABC's The path to 9/11: Not the HOW but the WHY. The Huffington Post. (Retrieved 10 September 2006). www.huffingtonpost.com/william-e-jackson-jr/the-hidden-agenda-ofabc_b_29150.html

Kiernan, $\bar{B}$. (2005, November 4). Lessons from Hiroshima to Vietnam and Iraq. Znet. (Retrieved 22 September 2006)

www.zmag.org/content/showarticl.cfm?ItemID $=9049$

King, D. A. (2004). Climate change science: adapt, mitigate or ignore? Science, January 9, 303: pp. 176-7. 